\title{
Becoming God: Cycles of Rebirth and Resurrection in Their Eyes Were Watching God
}

\author{
Kaitlynn N. Milvert, Department of English, Indiana University - Bloomington
}

Faculty Mentor: Dr. Christoph Irmscher

\begin{abstract}
This paper reexamines African-American writer and anthropologist Zora Neale Hurston's presentation of the self in Their Eyes Were Watching God (1937), generally considered one of the most important African-American novels of the twentieth century. Originally criticized by Hurston's contemporaries as a retrograde folk portrait of African-American life, Their Eyes presents the oral narrative of Hurston's protagonist, Janie, a woman surrounded by natural and social cycles. Building on the novel's allusive title and the convergent Biblical and folkloric frameworks of the work, I trace the evolving concept of "God" throughout the novel as external forces continually shape and reshape Janie's world for her, questioning whether she can retain any individual agency navigating through these cyclical, predetermined pathways. The redefined vision of the individual that emerges from this reading counters the criticism of Hurston's contemporaries, as Janie herself assumes the role of "God" at the novel's conclusion and gains the power to create her own cycles, free from external control. I thus argue that the novel transcends its supposed function as a depiction of the African-American self to make a broader, humanistic claim for the power of the individual, not contingent on social distinctions.
\end{abstract}

KEYWORDS: Their Eyes Were Watching God, African-American literature, cycles, God, folklore

Z ora Neale Hurston, author of the canonical novel Their Eyes Were Watching God (1937), is a difficult figure to pin down, and her novel is no less problematic. A writer and anthropologist during the male-dominated Harlem Renaissance era, Hurston was foundational in establishing the female African-American voice in modernist literature, and Their Eyes represents, perhaps, the first modernist novel by an African-American woman to gain a place in the canon (Gates, 2006). But contradictions underlie these progressive achievements. Often dubbed a social conservative, Hurston controversially opposed the Brown v. Board of Education ruling, asserting that integration of schools would more directly implant racial stratification in the education system (Hurston, 1995). To add another layer of complication, Hurston generally turns away from explicitly addressing political issues in her writing, choosing to focus instead on African-American folk culture and tradition during an era of politically progressive artistic production.

As Henry Louis Gates, Jr. (2006) notes, "It is this complexity that refuses to lend itself to the glib categories of 'radical' or 'conservative,' 'black' or 'Negro,' 'revolutionary,' or "Uncle Tom"' (p. 196). And it is this complexity that has puzzled critics since the first publication of Their Eyes, a novel that merges tradition with progressivism and questions what the "black novel" is or should be (Gates, 2006, p. 200). Nevertheless, I would suggest that the common thread that unites Hurston's contradictions is her belief in the individual. This essay is a fresh attempt to reframe the novel's polarities in the unified context of individualism, much in the same way the African-American folklore that Hurston so valued endeavors to do.

"Even the Bible was made over to suit our vivid imagination" (p. 19), muses Hurston (1935/1969) in the opening pages of her collection of African-American folklore, Mules and Men. Defining folklore as "the first thing that man makes out of the natural laws he finds around him" (p. 183), Hurston (1991) acknowledges African-Americans' skill at intricately interweaving folk elements into a Biblical framework to create an explanation of their world - a world formed not only by the governing laws of nature but also by the human-imposed construct of slavery.

Janie, Hurston's protagonist in Their Eyes Were Watching God, finds herself caught within a similar dualism, as layers of natural and social cycles envelop her life, ranging from the daily recurrence of sunrise and sunset to the generational inheritance of racial oppression and gender roles. The closed form of the cycle suggests the same sort of immutable "natural laws" that folklore and religion seek to explain, and Janie initially looks externally for an explanation of her world. However, she also comes to recognize the alternative possibility of the cycle as a form that allows new beginnings. In accordance with the dynamic role of God in AfricanAmerican folklore, these interlinked and shifting concepts of external control and individual rebirth raise the question of who the elusive "God" of the title is, and I argue that as Janie finds the power to shape her own cycles, she becomes her own "God" and creates her own "natural laws."

Of course, not all readers have found the novel so empowering. Several of Hurston's contemporaries, notably Richard Wright and Alain Locke, whose works focus on socially-minded, often embittered, portrayals of racial injustice, saw Their Eyes as a step backward in the agenda for African-American social progress, rather than an assertion of individualism. Certainly, Hurston celebrates folk roots 
and African-American community, which Wright criticizes as a continuation of the "minstrel technique that makes the 'white folks' laugh" (as cited in Beauchamp, 2014, p. 73). However, I contend that the folkloric cycles that Hurston presents in her novel in fact resemble the restrictive external forces that Wright and Locke fight to change. The fact that Janie is not able to alter these cycles and, instead, finds the internal agency to create her own cycles shows the power of the individual to transcend the constraints of social and cultural limitations. My reading, therefore, recasts Their Eyes as not merely a tale of the African-American self in the social world, but rather a broader, humanistic celebration of the individual, regardless of external influences at work.

\section{FOLKLORIC VISIONS AND BIBLICAL CREATION}

The scene Hurston paints in her opening pages effectively situates Janie's tale liminally between Biblical and cultural contexts as well as between social and natural spheres. As Janie walks through Eatonville, the townsfolk's eyes "watch" her in an ironic, even heretical, reprisal of the title, for the men marvel at Janie's sexuality and the women "hope that she might fall to their level some day" (Hurston, 1937/2006, p. 2). On the town's porch, a locus of folk expression, they "s[i]t in Judgment" (p. 1) and tell tales to explain Janie's empowerment, which remains beyond their understanding. Janie bypasses the front porch and progresses to her own back porch, a place Dale Pattison (2013) identifies as her individual "site of resistance" to social judgments. With her friend Pheoby as her sole companion, Janie begins her own tale, and, while "the kissing, young darkness [becomes] a monstropolous old thing" (Hurston, 1937/2006, p. 7), Janie takes us, her implicit listeners, back to the morning of her youth.

At the outset of what she terms her "conscious life" (Hurston, 1937/2006, p. 10), Janie's folkloric understanding defines her interaction with natural cycles as she embraces their influence on her life, believing a higher, omnipotent God to control them. With the coming of spring, the season of rebirth, Janie lingers beneath a blossoming pear tree and marvels at the heightened awareness that springtime stirs in her. Awakened by the new life flourishing around her and curious about her own budding existence, Janie searches the garden for "answers" and finds herself standing at her grandmother's gate, "waiting for the world to be made" (p. 11). Janie finds an explanation, if not an answer, through folktales, for young Janie knows "that God [tears] down the old world every evening and [builds] a new one by sun-up" (p. 25). Janie thus imputes to God the power of creation and rebirth through cycles, leaving her passively watching and waiting for God the Creator to "make" her world for her.

In this interval of hesitation, Janie's grandmother, Nanny, replaces Janie's folkloric vision of God and nature with one of social subjugation. Because of her past as a slave, a slave master, rather than springtime or sun-up or God, shaped Nanny's world for her. In consequence, Nanny has no tale of resplendent creation, but instead offers a repressive account of the social cycle in which the black woman is "de mule uh de world" (Hurston, 1937/2006, p. 14). She elucidates how the white man "throw down de load" (p. 14) and assigns the black man the labor of picking it up - only for him to dump it upon the black woman's back.

Nanny, therefore, arrogates the role of "God" as she summons Janie into the house and interferes with her springtime awakening, resolutely structuring Janie's new world according to her own social vision. She believes that a stable marriage to a small-time landowner, Logan Killicks, will elevate Janie above the social cycle and compels her into a union with him, "desecrating the pear tree" (Hurston, $1937 / 2006$, p. 14) by forcing Janie to defy her springtime intuition. Ironically, by depriving Janie of her liberty, Nanny only thrusts Janie into the cycle of subservience; after they marry, Logan even buys a mule so that Janie can work the fields, an explicit imposition of her social role. Insensible to the inherent contradiction in her actions, Nanny arranges the wedding in the evening in her parlor. Thus, Nanny, as "God," tears down Janie's old world of pear trees and possibilities and constructs a new one of mules and monotony in its stead.

Janie remains static in her social role until the resurgence of natural cycles circumvents Nanny's claim to divinity and restores Janie to the realm of possibilities. As testament to her incomplete control over cycles, Nanny cannot evade the natural cycle of death and, before she dies, officially relinquishes her role as "God," telling God in prayer, "De rest is left to you" (Hurston, 1937/2006, p. 24). Free from the control of her first "God," Janie once again finds herself attuned to the springtime rebirth of the natural world and begins to "expect things" (p. 25).

Watching the road beyond the gate, Janie's eye catches on a "citified, stylish dressed man" (Hurston, 1937/2006, p. 27), Jody Starks, who speaks of possibilities beyond pear trees and garden gates. With his "big voice" (p. 28), Jody allures Janie with ambitious talk of "building" a new town. Although Janie admits to herself that Jody does "not represent sunup and pollen and blooming trees" (p. 29), his prophetic speeches hold sway over her and carry her beyond both mules and springtime visions into grandiose images of the "far horizon" (p. 29). Abandoning Logan and his mule, Janie marries Jody at sunset, and they watch "the sun plunge into the same crack in the earth from which the night emerged" (p. 33). As nighttime ominously ascends, Jody now assumes the role of "God," this time rebuilding Janie's world in the form of a town: Eatonville.

In a fictional replication of the "burly, boiling, hardhitting, rugged-individualistic setting" (p. 12) that Hurston (1942/1984) once called home, Eatonville alters the established social cycle of racial and gender subjugation. Because Eatonville historically was one of the first incorporated all-black towns, the issue of racial oppression disappears in the town, instead allowing for uninhibited African-American individualism and folk expression. 
However, in the absence of racial strata, Jody adds an additional dimension of "upward mobility" (Gates, 2006, p. 197) by instituting a class system in the community. Jody proclaims himself the town's mayor and, through a linguistic nuance, explicitly elevates himself to the role of "God" with his frequent emphatic, "I god," instead of "my God" (King, 1990).

Through this dual authority as "God" and mayor, Jody seeks absolute dominion over the cycles within Eatonville. Endeavoring to control the rising and the setting of the sun - and, therefore the reconstruction of the world - Jody installs a street lamp outside his town store. Janie's life, in consequence, can never be rebuilt anew each day; rather, it becomes a cycle of tedious, mechanical repetitions, "as each morning the world [flings] itself over and expose[s] the town to the sun... and every day ha[s] a store in it, except Sundays" (Hurston, 1937/2006, p. 51). While Jody does not subject Janie to hard labor, he does not liberate her from her role as a mule either. Exemplifying Janie's modified social role, Jody at one point buys an overworked mule in the town and sets it free, only for it to die from "bare, bare fat" (p. 62) as the townsfolk spoil it. Jody likewise frees Janie from hard labor when he marries her; however, she, too "dies" from her listless life in the store.

Nevertheless, Jody's self-bestowed "divine right" to power in Eatonville turns out to be a deception as he, too, succumbs to the natural cycle of death, freeing Janie from another false "God." With Jody's death, Janie's springtime returns. Although she dresses in the "expensive black folds" of mourning, internally, she experiences "resurrection and life" (Hurston, 1937/2006, p. 88), and her personal visions can return in spite of external social distinctions. Having seen her world torn down and rebuilt with each of her two marriages - each beginning with a sunset and ending with a sunrise Janie metaphorically rises again on the third day with the possibility to rebuild her own world. Her resurrection marks a convergence in the Biblical and folkloric frameworks of the narrative, for, as Eva Boesenberg (1999) observes, the traditional folktale follows a defined tripartite model, which takes shape through Janie's series of three marriages. The beginning of the third stage of Janie's "quest" (Boesenberg, 1999, p. 64) in the folktale structure therefore coincides with her resurrection in the Biblical realm. While in terms of folklore we would expect a forthcoming resolution at this point, the resurrection suggests an opposite trajectory, and this dichotomy anticipates the significantly more complicated third iteration in Janie's cycle of marriages.

\section{QUESTIONING THE RESURRECTION}

When Janie again enters into a relationship, it is with Tea Cake Woods, who embodies her long withheld springtime desires and further enables Janie to explore her independence as "God." At last Janie's "bee to a blossom - a pear tree in the spring” (Hurston, 1937/2006, p. 106), Tea Cake draws Janie into complete harmony with the natural cycles that she had previously maintained on the periphery and distances her from the control of social cycles. With disregard for such superficial social distinctions as age, status, and wealth, Tea Cake professes his love for Janie not only at nighttime before the world has been "torn down," but also in the morning after its reconstruction. Janie, now assured of his love, fully defies social expectations and runs off to marry Tea Cake. The two wed in the morning, signifying creation rather than destruction; becoming "God" in their union, Tea Cake and Janie together "make" their new world.

Now divorced from the rigid social construct of Eatonville, the couple chooses to exercise their "divine" power of creation among nature in "de muck" (Hurston, 1937/2006, p. 128) of the Everglades, where they establish their conjugal existence. They create a world that reflects young Janie's springtime awakening, in which mules disappear and nature becomes a reflection of the self. Manifesting this vision, Janie and Tea Cake pick beans together in the Everglades and share the load, rather than dumping it upon Janie's back, which allows Janie at last to transcend her status as a "mule." Even though others "work all day for money and fight all night for love" (p. 131), Tea Cake freely intermixes work and love as he spends his days laboring alongside Janie, not dividing his time based on human constructions of day and night. Similarly, Tea Cake and Janie stay for an entire cycle of seasons, waiting for the next harvest, whereas other workers adhere to social custom and leave the Everglades with the changing of the seasons. Tea Cake and Janie thus deepen their connection with the natural world as they live in harmony with natural cycles, while they choose to reject the constraints of the social sphere.

Arguably, this pastoral scene becomes too idealistic - and even deceptive - in its portrayal of Tea Cake and Janie's life in the Everglades. In reality, as Kathleen Davies (1992) points out, the plantation of the Everglades "is built on racism, white bosses' owning and running the fields" (p. 153). While Tea Cake and Janie insulate themselves from this apparent racial oppression, they have not truly escaped from social cycles; their perception has changed while reality has not. A similar shift in Janie's narrative perspective reveals how this insular view challenges Janie's female liberation as well. As Boesenberg (1999) emphasizes, Tea Cake is, in some ways, no less flawed than Janie's previous husbands. Tea Cake does beat Janie at one point, and her narrative voice becomes ostensibly silent during this chapter. Since, as readers, we do not hear Janie's thoughts on the beating, we do not view it as the same sort of atrocity that we do the abuses of her previous marriages. Yet, the reality of the situation suggests that Tea Cake and Janie's role as "God" is another false, if more felicitous, construction, made attractive by its connection with Janie's original springtime visions. The ambiguous dividing line between perception and reality questions whether their agency is merely an illusion, as they do not truly extricate themselves from the omnipresent cycles but simply refuse to see them.

As if answering this concern, a "senseless monster" (Hurston, 1937/2006, p. 158) - a hurricane - soon stirs 
in its sleep and, in its mighty power, challenges Tea Cake and Janie's authority as "God." The storm, though a natural force, does not fit into Tea Cake and Janie's comprehension of cycles, but rather is a disruption in their world. Personified as a "monstropolous beast" (p. 161), the hurricane possesses its own will and, acting as an unpredictable, autonomous being, seizes control over the natural and social spheres of the world in one sweeping wave. Imposing a prolonged "night" (p. 158) on the world, the storm tears down the world in a literal sense and effaces all social and natural cycles in the process; not promising reconstruction with sun-up, the hurricane now becomes a corrupt embodiment of "God."

Initially reluctant to desert their idyllic existence in the Everglades, Tea Cake and Janie soon recognize that they have no control over the chaos of the "beast" and look to the existence of some higher power, leaving "their eyes... watching God" (Hurston, 1937/2006, p. 160) for an explanation of the uncontrollable. Tea Cake and Janie nevertheless resist passive resignation to the storm and flee the hurricane, wrestling for agency over their lives. Not even folklore can offer a rational explanation for the storm, for, as James Krasner (1989) states, "The chaos of nature cannot be made simplistically metaphorical” (p. 124). Indeed, Tea Cake and Janie witness animals being whipped around in a wild scene of folkloric disorder, and, in a culmination of chaos, Tea Cake fights a rabid dog in the middle of the storm to protect Janie from its savage violence. Physically struggling with a "beast," an animalistic embodiment of the storm, Tea Cake triumphs in his battle and kills the depraved dog, suffering only one seemingly insignificant bite. Tea Cake and Janie believe to have won their quarrel with control, and the storm soon abates as they reach safety in Palm Beach, where they arrive at sun-up, the destroyed world already being rebuilt.

Amidst all of the death and destruction of the hurricane, humans waste no time in reconstructing racial divisions. Even though "nobody can't tell nothin' 'bout some uh dese bodies, de shape dey's in. Can't tell whether dey's white or black" (Hurston, 1937/2006, p. 171), the white authorities of Palm Beach, playing the part of "God the Judge," dictate that only "white" people be buried in coffins. Anna Lillios (1993) comments that, while Hurston mythicizes her portrayal of the hurricane, it in fact accords with the historical facts of the 1928 Okeechobee Hurricane. Certainly, Hurston nods to the social injustice of the situation through her account of the corrupt burial process. Yet, what Lillios alludes to but does not critique is Hurston's decision to avoid mentioning the vast racial discrepancies in the death tolls: roughly three quarters of the victims were black migrant workers. Hurston's fragmentary depiction of reality mirrors Tea Cake and Janie's selective view of their situation in the Everglades and suggests an underlying desire to steer the novel away from social realism, a genre that Hurston terms "the sobbing school of Negrohood" (as cited in Gates, 2006, p. 199). Keeping the focus on the individual rather than on larger racial issues, Tea Cake and Janie avoid extensive social commentary and expeditiously leave the social cycles of Palm Beach to return to "de muck," where they arrive in the morning in an attempt to rebuild their lives.

However, the hurricane has already perverted the natural cycles of the Everglades and disillusioned Tea Cake and Janie to their limited agency, which poses a threat to their power as "God." Although they pass three weeks in relative normalcy, Tea Cake soon sickens, having contracted rabies from the dog in the hurricane. The bestial chaos of the storm passes on to Tea Cake, creating a new, corrupt cycle, and, helpless as she was in the face of the hurricane, Janie cannot avert Tea Cake's transformation into a savage beast. She can only observe as he walks with a "queer loping gait, swinging his head from side to side and his jaws clenched in a funny way" (Hurston, 1937/2006, p. 182-183). His animalistic descent nearly complete and his human consciousness absent, Tea Cake attempts to shoot Janie. In an assertion of her individual agency, Janie instead fires first and kills Tea Cake. In doing so, Janie not only wrests control over the uncontrollable, but she also tragically sacrifices a part of herself.

A trial for her rebellion against external control, Janie faces her Day of Judgment in court for killing Tea Cake, testing the integrity of her authority as "God." In front of a jury of twelve white men, she does not "plead to anybody," but rather "just [sits] there and [tells]" (Hurston, 1937/2006, p. 187). The jury, in their apostolic capacity, hears Janie's truth as if the "Word of God" and at last frees her fully, affirming her divine ascendancy in spite of the social tensions in the courtroom. "So the sun [goes] down" (p. 188) on Janie's judgment day, leaving her with complete agency in rebuilding her world and its cycles.

\section{BECOMING GOD}

As her own autonomous "God," Janie's reconstruction of the world after the chaos of Tea Cake's death takes on a radically different form from her attempted restoration following the hurricane. Perhaps desiring to forget her powerlessness in the face of the uncontrollable in the Everglades, Janie does not return to "de muck" as before but buries Tea Cake "out of the way of storms" (Hurston, 1937/2006, p. 189) in Palm Beach. Her resolution to bury him there in a "strong vault" (p. 189) reprises the earlier injustices in Palm Beach after the hurricane, and Janie defies social cycles on an individual level by giving Tea Cake the burial that other black people were denied. Nevertheless, Janie has realized that she has no power to control natural or social cycles in a larger context. With the hurricane and Tea Cake's subsequent death, her springtime visions of natural cycles in the Everglades failed to afford her any agency, and she at last discovers that she must construct her own cycles to find self-definition. Janie thus returns to Eatonville, the center of folklore, to reshape her folkloric visions of the world in accordance with her new individualistic comprehension of cycles.

Back in Eatonville, Janie's narrative to Pheoby comes full circle and, recognizing the renascent potential of cycles, Janie 
now explores her ability as "God" to spark rebirth and even create. Gurleen Grewal (2010) remarks rather offhandedly how the beginning and the end of the novel display "a remarkable economy and unity of expression, much like that of a lyric poem" (p. 103), which raises a compelling point. Janie, by looking internally rather than externally for self-definition, actualizes her ability not only to explain her life through folklore, but to "make" her own world through poesis, the literal act of making. The final paragraphs contain a confluence of poetics, folklore, and spirituality as Janie merges her poetic ability to create with her folkloric views of the world and her agency as "God." With a poetic reading of the novel's end, the concluding scene gains a symbolic clarity that illustrates Janie's transcendent realization of selfhood.

As Pheoby leaves, Janie contemplates that "room upstairs," and with the doors "shut and fastened" (Hurston, $1937 / 2006$, p. 192), she climbs the staircase as if ascending to heaven. With her ascension, Janie's "shadow [falls] black and headlong down the stairs" (p. 192) as she casts off racial distinctions. Then, in a Pentecostal scene, an image of the Spirit descends upon Janie in her locked house as lamplight "wash[es] her face in fire" (p. 192) and wind blows through her windows. With these metaphorical tongues of fire, the narration becomes increasingly poetic, and we hear the sound of the wind echoed in rich consonance: "commenced to sing, commenced to sob and sigh, singing and sobbing" (p. 192). The wind implicitly takes on the traditional birdlike form of the Spirit as the "song of the sigh [flies] out of the window and [lights] in the top of the pine trees" (p. 193).

Inundated with the creative power of the Spirit, Janie reshapes the natural cycles as she changes her adolescent vision of the transient, seasonal pear tree into one of evergreen pine trees. She redefines the cycle of sunrise and sunset as she resurrects Tea Cake, her sacrificial victim, through remembrance, wrapping him "with the sun for a shawl" (Hurston, 1937/2006, p. 193). Now, as a triune God, Janie transcends the limitations of her gender as we see Janie's womanhood alongside Tea Cake's masculinity and the Spirit's androgynous aesthetic, transforming Janie into a female form of God the Father. At last, in a cyclical motion of complete agency, Janie "pull[s] in her horizon. Pull[s] it from around the waist of the world and drape[s] it over her shoulder" (p. 193). As she encircles herself with the horizon, Janie herself becomes the world, at last realizing her capability to make her own world within herself.

Then Hurston herself becomes "God" in a sense as she shapes the novel itself into a cycle. Having commenced her work with an observation of "Watchers" (Hurston, $1937 / 2006$, p. 1) who stare out at the horizon, searching for their dreams, Hurston concludes this thought in her final lines as Janie "call[s] in her soul to come and see" (p. 193). In ending the novel where it begins, we as readers perceive the transition between the passivity of "watching" and the insightful activity of "seeing." As we at last "see" the cycles set up in Janie's life, her tale can be retold through oral tradition, and the end becomes a new beginning. We then recognize perhaps the most important element of folklore in the novel - its demand to be repeated.

What intrigues me is how vehemently Hurston denied the presence of folklore in Their Eyes. In response to Alain Locke's criticism of her folk characters as "pseudoprimitives," Hurston asserted that "there is not a folk tale in the entire book," and threatened memorably, "I will send my toe-nails to debate him on what he knows about Negroes and Negro life - and I will come personally to debate him on what he knows about literature on the subject" (as cited in Hemenway, 1977, p. 241-242). Whether her toe-nails ever made their planned appointment with Locke is uncertain; what is less debatable is that folklore clearly forms an integral part of the novel, both thematically and structurally - through mules as well as three-part tales.

Ultimately, I think Hurston's ardent rejection of classification of her novel as a folktale reflects how she does not want her novel to turn into a didactic work or a piece of anthropology, and especially not a reductive social statement. Rather, in rejecting social realism, the novel becomes a humanistic celebration of the self and the Godlike potential that each individual possesses, regardless of external distinctions. As Hurston (1942/1984) affirms in her autobiography, "We will go where the individual drive carries us... It is up to the individual... That is one of the strongest laws that God made" (Hurston, 1942/1984, p. 237). Janie, in the end, accepts this as her "natural law," too. Through Janie's life, Hurston presents the empowering idea that we as humans retain the agency to control the cycles within our lives and to choose how to define our relationship with those that lie outside our immediate reach. With all of our "watching" the horizon for our dreams, we find that it is within our grasp if we "see" inside and find the "God" within us.

\section{AUTHOR INFORMATION}

All correspondence should be sent to kmilvert@indiana.edu.

\section{ACKNOWLEDGMENTS}

The author would like to thank Christoph Irmscher for his feedback and guidance throughout the research for and writing of this manuscript.

\section{REFERENCES}

Beauchamp, G. (2014). Three notes on Hurston's "Their eyes were watching God.” Texas Review, 35(1,2), 73-87.

Boesenberg, E. (1999). Gender, voice, vernacular: The formation of female subjectivity in Zora Neale Hurston, Toni Morrison and Alice Walker. Heidelberg: Universitätsverlag C. Winter. 
Davies, K. (1992). Zora Neale Hurston's poetics of embalment: Articulating the rage of black women and narrative self-defense. African American Review, 26(1), 147-159. http://doi.org/10.2307/3042084

Gates, H. L., Jr. (2006). [Afterword]. Zora Neale Hurston: "A Negro way of saying." In Z.N. Hurston, Their eyes were watching God (pp. 195-205). New York, NY: Harper Perennial.

Grewal, G. (2010). Beholding "A great tree in leaf”: Eros, nature, and the visionary in Their eyes were watching God. In D. G. Plant (Eds.), The inside light: New critical essays on Zora Neale Hurston (pp. 103-112). Santa Barbara, CA: Praeger.

Hemenway, R. E. (1977). Zora Neale Hurston: A literary biography. Chicago, IL: University of Illinois Press.

Hurston, Z. N. (1969). Mules and men (2nd ed.). New York, NY: Negro Universities Press. (Original work published 1935)

Hurston, Z. N. (1984). Dust tracks on a road (2nd ed.). Chicago, IL: University of Illinois Press. (Original work published 1942)

Hurston, Z. N. (1991). Folklore and music. Frontiers: A Journal of Women Studies, 12(1), 183-198. http://doi. org/10.2307/3346585

Hurston, Z. N. (1995). Court order can't make races mix. In Z. N. Hurston, Folklore, memoirs, and other writings (pp. 956-958). Library of America. Retrieved from https://www.loa.org

Hurston, Z.N. (2006.) Their eyes were watching God (1st Perennial Modern Classics ed.). New York, NY: Harper Perennial. (Original work published 1937)

King, S. (1990). Naming and power in Zora Neale Hurston's "Their eyes were watching God." Black American Literature Forum, 24(4), 683-696. http://doi.org/ $10.2307 / 3041796$

Krasner, J. (1989). The life of women: Zora Neale Hurston and female autobiography. Black American Literature Forum, (1), 113-126. http://doi.org/10.2307/2903995

Lillios, A. (1998). “The monstropolous beast": The hurricane in Zora Neale Hurston's "Their eyes were watching God.” Southern Quarterly, 36(3), 89-93.

Pattison, D. (2013). Sites of resistance: The subversive spaces of "Their eyes were watching God." MELUS, 38(4), 9-31. Retrieved from http://www.oxfordjournals. org

Simmons, R. (2002). “The hierarchy itself”: Hurston's "Their eyes were watching God" and the sacrifice of narrative authority. African American Review, 36(2), 181-193. http://doi.org/10.2307/1512254 